\title{
ANALISIS PEMAHAMAN GENERASI MUDA TERHADAP BAHAYA RIBA
}

\author{
Reni Ria Armayani, M.E.I ${ }^{1}$ Wika Lutfiah Sakinah ${ }^{2}$, Desvira Utami Rahmadini ${ }^{3}$, Putri \\ Hermayani ${ }^{4}$, Zizah Chairani ${ }^{5}$ \\ 1,2,3,4,5 Fakultas Ekonomi dan Bisnis Islam, UIN Sumatera Utara
}

Email Corespondent : zizahchairani01@gmail.com

\begin{abstract}
In today's modern era, the younger generation is a very influential component for this era. Because the younger generation will continue to live in the future. The understandings that our young generation must know today are related to academic, socio-cultural, economic and religious matters. Islam has summarized everything, in Islam it has been taught what is called Islamic economics. The basic principle of Islamic economics is that all economic activities are based on the Qur'an and hadith which prohibit the practice of usury. Riba is an addition to payments that must be met when there will be debt-receivable transactions or borrowing and buying and selling. This research aims to see how far the younger generation understands the dangers of usury and to what extent the younger generation contributes to usury-free economic activities. We conducted a survey on generations in Medan City, using qualitative methods, we can find out that the younger generation in Medan City already know that usury is haram but still in some activities they still use this practice of usury. From the results of this study, it is hoped that all young people will leave usury and participate in building a sharia economy that is free of usury.
\end{abstract}

Keywords : Young Generation, Usury, Islamic Economics, Sharia Banking

\begin{abstract}
Abstrak: Di zaman modern sekarang ini generasi muda merupakan komponen yang sangat berpengaruh untuk zaman ini. Karna generasi muda yang akan melanjutkan kelangsungan hidup kedepaanya. Pemahamanpemahaman yang harus di ketahui oleh generasi muda kita sekarang terkait dengan akademik, sosial budaya, ekonomi dan agamis. Islam telah merangkum semuanya, dalam islam sudah diajarkan yang namanya ekonomi islam. Prinsip dasar dari ekonomi islam ini adalah semua kegiatan ekonomi itu berlandaskan Al-qur'an dan hadist dimana didalamnya melarang praktik riba. Riba merupakan bentuk tambahan dalam pembayaran sebagai tuntutan yang harus dipenuhi saat akan terjadi transaksi hutang-piutang ataupun pinjam-meminjam dan jual beli. Penelitian ini dilakukan bertujuan untuk melihat seberapa jauh pemahaman generasi muda terhadap bahaya riba dan sudah sejauh apa generasi muda berkontribusi dalam aktivitas ekonomi yang bebas riba. Kami melakukan survey pada generasi di kota medan, dengan menggunakan metode kualitatif, kita dapat mengetahui bahwa generasi muda di kota medan sudah mengetahui bahwa riba itu haram tetapi tetep saja dalam beberapa aktivitas mereka masih menggunakannya praktik riba ini.
\end{abstract}


ANALISIS PEMAHAMAN GENERASI MUDA TERHADAP BAHAYA RIBA

Reni Ria Armayani, M.E.I ${ }^{1}$ Wika Lutfiah Sakinah ${ }^{2}$, Desvira Utami Rahmadini ${ }^{3}$, Putri Hermayani ${ }^{4}$, Zizah Chairani ${ }^{5}$

Dari hasil penelitian ini diharapkan seluruh generasi muda agar meninggalkan riba dan ikut membangun ekonomi Syariah yang bebas riba.

Keywords : Generasi muda, Riba, Ekonomi islam, Perbankan Syariah

\section{PENDAHULUAN}

Islam adalah agama Rahmatan lil'alamin, agama pembawa rahmat bagi semua makhluk Allah yang ada di bumi. Islam sendiri sudah mengatur tentang semua hal yang ada di muka bumi ini. Mengenai apa saja yang boleh kita lakukan dan yang tidak boleh kita lakukan. Agama islam mengatur tentang semuanya baik dari segi kesehatan, sosial, pendidikan, politik, ekonomi, dan masih banyak lagi. Berbicara tentang konteks ekonomi tidak lepas dari konsep yang sudah agama Islam berikan.

Agama Islam sudah memberikan penjelasan bagaimana cara umat islam untuk menjalankan ekonomi sesuai syari'ah. Membatasi mana yang baik dan halal untuk dikonsumsi dan di lakukan juga memberi batasan untuk hal-hal yang tidak boleh dilakukan atau diharamkan. Dalam konteks yang tidak boleh dilakukan ini biasanya disebut dengan riba.

Riba dalam bahasa Indonesia dapat diartikan sebagai bunga. Namun menurut istilah, riba merupakan bentuk tambahan dalam pembayaran sebagai tuntutan yang harus dipenuhi saat akan terjadi transaksi hutang-piutang ataupun pinjam - meminjam. Sedangkan menurut istilah fiqih, riba merupakan pengambilan tambahan dari harta pokok secara bathil baik dalam transaksi jual beli maupun pinjam meminjam. (Salimudin, Mumud, 2021)

Riba sendiri berarti tambahan pembayaran tanpa adanya ganti sebagai syarat transaksi utang piutang. Dalam Alqur'an sendiri sudah dijelaskan tentang bahaya riba ini, misalnya dalam Q.S. AlBaqarah:276 dan 278 yang menjelaskan tentang Allah memerintahkan kepada kita orang yang beriman untuk meninggalkan dan memusnahkan riba karena Allah tidak menyukai hal tersebut dan jika dia masih menggunakan riba maka ia akan bergelimangan dosa.

Riba dan kegiatan perbankan seperti sesuatu yang tidak dapat dipisahkan. Para ulama sepakat bahwa salah satu bentuk pengambilan riba yang diharamkan adalah sistem bunga yang ada di bank konvensional. Islam melarang keras kegiatan muamalah yang mengandung dan menimbulkan riba. Solusi dari hal tersebut maka didirkanlah bank yang tidak memberlakukan sistem bunga, sehingga sesuai dengan pokok ajaran Islam. 
Sebagian besar ulama berpendapat bahwa bunga yang berlaku dalam bank merupakan riba sehingga hukumnya menjadi haram. Dengan demikian maka didirikanlah bank yang menggunakan sistem tanpa bunga pada nasabahnya yang kemudian dikenal dengan sebutan perbankan syariah.

Untuk mengembangkan perbankan syariah tentunya sangat dibutuhkan peran umat muslim itu sendiri terutama dari generasi muda muslim yang paham betul akan bahaya riba. Sebagai Negara dengan populasi mayoritas islam terbanyak di dunia, maka menjadi suatu yang wajib bagi para generasi muda untuk mempelajari prinsip-prinsip ekonomi syariah terutama bagaimana riba sangat dilarang dalam Al-Qur'an agar ekonomi islam dapat tumbuh dengan baik dan membawa kemaslahatan bagi semua orang.

Gerenasi muda ialah sekelompok masyarakat yang mengharapkan penghargaan dan peran dalam masyarakat, dan kejelasan masa yang akan datang. Maka dari itu generasi muda muslim wajib mengetahui apa itu bahaya riba agar kedepannya roda ekonomi yang di jalankan sudah sesuai dengan prinsip syariah seperti yang sudah ajarkan dalam Al-Qur'an dan hadist.

Dalam hidup manusia hanya mencari keberkahan atas apa yang dia kerjakan. Lantas umat muslim di tuntut untuk melakakukan hal yang hanya di perintahkan oleh Allah SWT. tak terkecuali dalam konteks ekonomi tadi. Umat muslim harus belajar mengenai ekonomi syari'ah dari semua golongan, tak terkecuali generasi muda umat muslim. Generasi muda di tuntut paham tentang bahaya riba. Hal ini dilakukan bukan adanya alasan.

Untuk mengetahui apakah generasi muda sudah memahami bahaya riba atau belum diperlukan adanya penelitian ini yang pada dasarnya peneli melihat beberapa aspek yang mendasar bahwa generasi muda muslim belum terlalu paham akan bahaya riba.

Adapun aspek permasalahan utama yang peneliti lihat adalah :

1. Peneli terlibat langsung dalam menjalankan ekonomi Syariah dan melihat langsung bahwa ada sekelompok generasi muda yang belum mengetahui bahaya riba.

2. Sejauh ini, walau sudah ada beberapa yang meneliti terkait dengan masalah ini, peneliti merasa bahwa generasi 
muda perlu memahami lebih dalam dan lebih jauh tentang bahaya riba.

3. Hasil penelitian ini akan memberikan manfaat yang bisa diaplikasikan oleh peneliti sendiri, generasi muda, dan pembaca karya ilmiah ini..

\section{TINJAUAN PUSTAKA}

\section{Pengertian Ekonomi Islam, Riba, dan Perbankan Syariah}

Ekonomi Islam (al-iqtishad) dapat diartikan sebuah pengetahuan tentang aturan yang terkait dengan produksi kekayaan, medistribusikan, dan konsumi. Umumnya ekonomi sendiri diartikan sebagai kajian yang mempelajari tentang perilaku manusia dalam hubungannya serta pemanfaatan sumber produksi yang langka untuk diproduksi atau dikonsumsi. Sedangkan ekonomi islam menurut abdul Mun'it al-Jamal ialah kumpulan dasardasar umum yang digali dari Al-qur'an dan Hadist. Pada dasarnya ekonomi islam merupakan penetapan syariat dalam aktivitas ekonomi. Pengertian inilah yang sangat cocok untuk dipakai dalam menganalisis persoalan-persoalan yang ada di tengah masyarakat. Misalkan bagaimana konsumsi masyarakat yang diajarkan dalam Islam, kebijakan fiskal dan moneter, investasi, asuransi, jual beli , serta pelarangan terhadap riba (Dr. Rozali, m.Ag,2014)

Riba sendiri sangat dilarang dalam islam. Kata riba pada bahasa Arab bisa berarti tambahan meskipun sedikit di atas jumlah uang yg dipinjamkan, hingga meliputi sekaligus riba dan bunga. Riba pada hal ini semakna dengan kata usury dalam bahasa Inggris yg berarti suku bunga yg lebih asal biasanya atau suku bunga yang mencekik. Tetapi pada ilmu ekonomi, riba merujuk pada kelebihan berasal jumlah uang utama yang dipinjamkan oleh si pemberi pinjaman berasal si peminjam. Dari berbagai definisi, dapat kita dsimpulkan bahwa riba ialah suatu aktivitas pengambilan nilai tambah yg membebankan/memberatkan dari akad perekonomian, mirip jual beli atau utang piutang, asal penjual terhadap pembeli atau asal pemilik dana kepada peminjam dana, baik diketahui bahkan tidak diketahui, sang pihak ke 2.(Salimudin, Mumud, 2021)

Secara teknis, riba mengacu pada pembayaran "premi" yang wajib dibayarkan peminjam pada pemberi pinjaman disamping pengembalian pokok menjadi Syarat pinjaman atau perpanjangan batas jatuh tempo. dalam pengertian ini, riba mempunyai persamaan 
makna serta kepentingan dengan bunga (interest). dengan demikian apabila dengan terjadinya pertukaran barang yang digolongkan kedalam ribawi, ukurannya wajib sama. jika seeorang menukar satu gram emas dengan orang lain,dia wajib menerima satu gram pula, bila terjadi kelebihan, hal tersebut ialah riba. Demikian juga, dalam melakukan kesepakatan Bila para pihak telah sepakat menukarkan barangnya dengan barang lain atau uang, wajib diserahkan secara tunai di waktu yang sama maupun keduannya. Disamping itu, ukuran harta yg dipertukarkan wajib diketahui jumlahnya ketika terjadi kontrak. dari penerangan diatas, terdapat beberapa unsur penting yang terdapat dalam riba, yaitu yang di tambahkan pada pokok pinjaman, besarnya penambahan menurut jangka waktu, serta jumlah pembayaran tambahan sesuai persyaratan yg telah disepakati. Ketiga unsur ini bersama-sama membentuk riba dan bentuk lain dari transaksi kredit dalam bentuk uang atau sejenisnya.(Hasriani, Wa Ode Titisalfia, Ammar Munir, 2020)

Dalam agama Islam praktik riba ini sangat dilarang karena hanya akan memeratkan satu pihak saja. Padahal dalam Islam sendiri Allah telah memberikan hal-hal yang baik untuk di kerjakan, tak terkecuali dalam permasalahan ekonomi sendiri. Dalam agama Islam sudah membarikan pemaparan tentang bahaya riba ini. Hal ini bisa kita lihat dari Firman Allah dalam surah Ali Imran : 130 yang berbunyi :

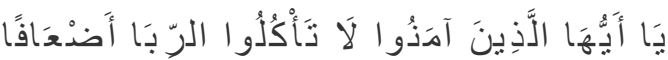

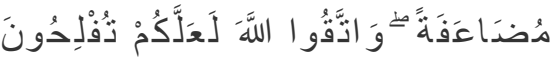

Artinya : "Hai orang-orang yang beriman, janganlah engkau memakan riba dengan berlipat ganda serta bertakwalah engkau pada Allah agar engkau menerima keuntungan."

Dalam ayat tersebut jelas bahwa Allah merang kita untuk melakukan praktik riba atau memakan riba. Karena sejatinya riba itu tidak membawa keberkahan bagi siapapun, riba hanya membawa kemudhartan saja.

Macam-Macam Riba Secara garis besar riba dikelompokkan menjadi 2, yaitu riba utang piutang dan riba jual beli. kelompok pertama terbagi sebagai riba qordh serta jahiliyah, sedangkan kelompok kedua terbagi menjadi riba fadl dan nasi'ah. 
1. Riba qardh, yaitu suatu manfaat yg disyaratkan terhadap yang berutang (muqtaridh).

2. Riba jahiliyah, ialah utang dibayar lebih asal pokoknya sebab si peminjam tidak bisa membayar ketika yang ditentukan. Riba jahiliah terjadi di riba utang dan riba pinjaman.

3. Riba fadhl, adalah riba yg terjadi di tukar menukar dua jenis arang yang kuantitasnya sama tetapi kualitasnya tidak sama.

4. Riba nasa' (nasi'ah), yaitu riba yng terjadi karena adanya penundaan saat pembayaran menggunakan memutuskan adanya dua harga yaitu harga kontan atau harga yg di naikkan sebab pembayarannya tertunda.

\section{Sebab-Sebab Dilarangnya Riba}

1. Baik al-Qur'an maupun hadis Nabi SAW mengharamkan riba, bahkan pada hadis dijelaskan bahwa semua pihak yang terlibat pada riba seperti orang yang mentransaksikan, memakan, mewakili, dan mencatat, dan menjadi saksinya di laknat oleh rasulullah. Larangan tadi bukan tanpa sebab.

Menurut al-fahr al-Razi, ada beberapa sebab dilarang serta diharamkannya riba tersebut. Riba memungkinkan seseorang memaksakan pemilik harta dari orang lain tanpa ada imbalan. Keuntungan yang diperoleh peminjam masih bersifat sepikulasi belum tentu terjadi, sedangkan pemungutan tambahan dari peminjam oleh pemberi pinjaman adalah hal yang pasti tanpa resiko.

2. Riba menghalangi pemodal ikut dan berusaha mencari rizki, sebab iya dengan mudahnya membiayai hidupnya cukup dengan bunga berjangka itu. Karena itu, iya tidak mau lagi memangku pekerjaan yang bekerjasama dengan dipakainya tenaganya atau sesuatu yang membutuhkan kerja keras.

Hal ini akan membawa kemunduran warga, sebagaimana dimaklumi bahwa dunia tidak bisa berkembang tanpa perdagangan, seni, serta ciptaan karya buah tangan.

3. Jika riba diperbolehkan, warga dengan maksud memenuhi kebutuhannya tak segan-segan meminjam uang walaupun bunganya sangat tinggi.

Hal ini akan merusak kata hidup tolong menolong, saling menghormati serta sifat-sifat baik 
lainnya, serta perasaan berhutang budi.

4. Dengan riba biasanya pemodal menjadi semakin kaya dan peminjam semakin miskin. Sekiranya riba dibenarkan, orang kaya akan menindas orang miskin menggunakan cara ini.

5. Larangan riba telah ditetapkan oleh nas dimana tak seluruh misteri tuntutannya diketahui oleh manusia. Keharamannya itu pasti, kendati orang tidak tau persis segi serta sebab pelarangannya. (Salimudin, Mumud, 2021)

Berikut ini adalah alasan yang menghalalkan riba :

1. Dalam keadaan darurat (sangat terpaksa)

2. Hanya kredit yang bersifat konsumtif saja yang diharamkan pengambilan bunganya, adapun yang produktif diperbolehkan.

3. Bank sebagai lembaga (badan hukum) tentunya berbeda dengan mukallaf (subjek hukum individu) yang dikenakan khitab firman Allah SWT.

4. Hanya riba yang berlipat ganda yang diharamkan, sedangkan suku bunga yang wajar masih diperbolehkan.
5. Kemaslahatan lebih besar dari bahaya yang ditimbulkan.

6. Bunga diberikan sebagai ganti rugi atas hilangnya kesempatan untuk memperoleh keuntungan dari pengelolaan dana tersebut.

7. Bunga diberikan sebagai kompensasi atas laju inflasi yang mengakibakan turunnya nilai mata uang atau daya beli.

8. Bunga diberikan sebagai imbalan atas pengorbanan untuk tidak menggunakan uang.(Arifin, 2013)

Pada dasarnya alasan utama pelarangan riba ini dikarenakan keberadaan riba dalam perekonomian sebagai bentuk sosial dan juga eksploitasi ekonomi, yang melanggar inti dari ajaran agama islam yang berkaitan sosial keadilan. Oleh karenanya penghapusan riba dalam sistem ekonomi ini bermaksud untuk memajukan keadilan ekonomi, soaial, etika seta moral dalam perilaku ekonomi yang baik dan benar. (zamir iqbal, 2011)

Bank syariah merupakan bank yang menjalankan prinsip Syariah dalam transaksi bisnis. Dalam islam bank Syariah telah menawarkan produk dan transaksi yang halal dan melarang transaksi yang melibatkan bunga 
didalamnya. Islam melarang ketat bunga (riba) karena memiliki dampak social. Hal ini dikarenakan hanya memberikan penghargaan atau keuntungan kepada orang-orang yang tidak berusaha. Transaksi berbasis riba ini memungkinkan si pemberi pinjaman hanya menerima keuntungan yang berkaitan dengan uang yang mereka pinjamkan, sedangkan risiko dan kerugian kesengsaraan untuk orang yang meminjam.(Maali et al., 2006)

Perbankan sangat vital perannya bagi perekonomian suatu negara. Bagi negara-negara maju seperti Jepang, Amerika, dan negara-negara di Eropa Bank menjelma sebagai tempat untuk melakukan semua teransaksi keuangan seperti, tempat menyimpan uang, tempat berinvestasi, pengiriman uang, dan juga tempat untuk melakukukan kegiatan pembayaran ataupun melakukan penagihan. Berbeda dengan yang terjadi pada negara berkembang, dimana sebagian besar pemahaman masyarakat mengenai bank masih sebatas pada tempat menyimpan dan meminjam uang saja.

Bank merupakan perusahaan yang bergerak pada bidang industri jasa. Hal ini dikarenakan bank mengeluarkan produk berupa pelayanan jasa kepada masyarakat. Sederhananya bank bisa diartikan sebagai lembaga keuangan yang kegiatan usahanya adalah mengumpulkan dana dari masyarakat lalu menyalurkan kembali dana tersebut pada masyarakat dalam bentuk kredit serta memberikan jasa-jasa lainnya yang dimiliki oleh bank tersebut untuk meningkatkan taraf hidup masyarakat.

Dalam Undang-undang Nomor 10 Tahun 1998 tentang Perbankan, Bank disebutkan sebagai badan usaha yang menghimpun dana dari masyarakat dalam bentuk simpanan dan menyalurkannya kepada masyarakat dalam bentuk kredit dan atau bentukbentuk lainnya dalam rangka meningkatkan taraf hidup masyarakat. Indonesia memberlakukan dua macam sistem operasional perbankan, yaitu bank konvensional dan bank syariah.

Menurut UU No. 21 tahun 2008 tentang Perbankan Syariah, Bank Syariah adalah bank yang menjalankan kegiatan usaha berdasarkan prinsip syariah, atau prinsip hukum islam yang diatur dalam fatwa Majelis Ulama Indonesia seperti prinsip keadilan dan keseimbangan, kemaslahatan, serta tidak mengandung gharar, maysir, riba, zalim 
dan obyek yang haram. Sedangkan pengertian bank konvensional menurut UU No. 21 tahun 2008 tentang perbankan syariah ialah, Bank Konvensional adalah Bank yang pengoperasionalan kegiatan usahanya dilakukan secara konvensional dan berdasarkan jenisnya, bank konvensional terdiri atas Bank Umum Konvensional dan Bank Perkreditan Rakyat.

\section{Selain itu, Undang-Undang} Perbankan Syariah juga memberikan amanah pada bank syariah untuk menjalankan tugas sosial dengan mengoperasionalkan lembaga baitul mal, yaitu dengan menerima dana yang berasal dari zakat, infak, sedekah, hibah, atau dana sosial lainnya untuk kemudian disalurkan kepada pengelola wakaf sesuai ketentuan dari pemberi wakaf. Dalam berkegiatan, perbankan syariah senantiasa berlandaskan pada prinsip syariah, demokrasi ekonomi, dan prinsip kehati-hatian. Berbeda dengan bank konvensional yang menerapkan sistem bunga, bank syariah menerapkan sistem bagi hasil. Perbankan syariah memiliki tujuan untuk berperan dalam memajukan kegiatan pembanhunan nasional dalam rangka peningkatan kesejahteraan rakyat, persatuan, dan juga keadilan yang merata bagi seluruh masyarakat.

Bank konvensional ialah bank yang melaksanakan aktivitas usaha secara konvensional yang mana pada kegiatannya memberikan jasa yang kemudian lintas pembayaran sesuai prosedur dan ketentuan yang sudah ditetapkan. Sedangkan Bank Syariah" artinya kata yang digunakan di Indonesia untuk menyatakan suatu jenis bank yang dalam pelaksanaannya sesuai pada prinsip syariah. tetapi, "Bank Islam" (Islamic Bank) merupakan kata yang dipergunakan secara luas dinegara lain untuk menjelaskan bank dengan prinsip syariah, disamping terdapat istilah lain untuk menyebut bank Islam antara lain interest free bank, lariba bank, serta sharia bank.

Pengertian bank syariah atau Bank Islam ialah Bank yang beroperasi sesuai menggunakan prinsip-prinsip syariah Islam. Bank ini norma beroperasinya mengacu pada ketentuan-ketentuan AlQuran dan hadist.

Bank yang beroperasi sesuai dengan prinsip-prinsip syariah Islam ialah Bank yang dalam beroperasinya itu mengikuti ketentuanketentuan syariah Islam, khususnya yang menyangkut 
norma bermuamalah dalam Islam. yang beroperasi sinkron dengan syariah Dalam norma bermualat itu dijauhi mulai bermunculan tetapi pemahaman praktik-praktik yang dikhawatirkan mengandung unsur-unsur riba, untuk diisi menggunakan aktivitas-aktivitas investasi atas dasar bagi hasil serta pembiayaan perdagangan atau praktik praktik perjuangan yang dilakukan pada zaman Rasulullah atau bentuk-bentuk perjuangan yang sudah terdapat sebelumnya, namun tidak dilarang oleh beliau.

Perbankan Syariah dalam melakukan kegiatan usahanya senantiasa berasaskan pada Prinsip Syariah, demokrasi ekonomi, dan prinsip kehatihatian. Perbankan Syariah bertujuan menunjang pelaksanaan pembangunan nasional dalam rangka meningkatkan keadilan, kebersamaan, dan pemerataan kesejahteraan rakyat.

Riba adalah memakan harta orang lain tanpa jerih payah dan kemungkinan mendapat resiko, mendapatkan harta bukan sebagai imbalan kerja atau jasa, menjilat orang-orang kaya dengan mengorbankan kaum miskin, serta mengabaikan aspek perikemanusiaan demi menghasilkan materi. Penduduk Indonesia mayoritas beragama Islam, sebagai akibatnya permintaan akan bank rakyat akan bank syariah masih sangat kurang dikarenakan minimnya promosi dari bank syariah serta akhirnya masyarakat menentukan buat bertransaksi pada bank konvensional dan kemungkinan itu sudah terjerumus dalam riba padahal riba sudah jelas dilarang dalam islam.(Haida et al., 2021)

\section{Pengertian generasi Muda}

Generasi muda, sebagai generasi penerus perjuangan bangsa yang ideal, akan memainkan peran kepemimpinan, mulai dari kepemimpinan keluarga hingga kepemimpinan bangsa dan negara. Generasi muda dengan kepribadian labil suka meniru dan mencari pengalaman baru, sangat mudah terpengaruh, serta modern dan trendi untuk dijadikan panutan dalam kehidupannya. Pada level mikro, misi dan tanggung jawab mendidik atau memajukan generasi muda adalah misi Allah SWT kepada kedua orang tua di rumah, namun pada level makro menjadi tanggung jawab bersama orang tua, guru sekolah, pemerintah, serta tokoh agama dan tokoh masyarakat di lingkungan masyarakat. 
Generasi dalam pengertian umum berarti semua orang yang hidup pada waktu yang hampir bersamaan. Kekuasaan; Derivatif; atau lamanya waktu orang tersebut hidup. Muda belum sampai setengah umur; sebagai lawan dari kata tua;. Berbeda dengan kata tua, generasi muda adalah orang-orang dengan usia harapan hidup yang hampir sama, yaitu sejak lahir sampai dengan usia sekitar 30 - 40 tahun. Zakiah Daradjat memberikan pemahaman kepada generasi muda dengan melihatnya dengan pemahaman yang lebih luas dan lebih sempit. Dikatakannya, generasi muda dalam arti luas meliputi usia anak-anak dan remaja sejak lahir hingga dewasa dalam segala aspek (fisik, mental, sosial, budaya dan ekonomi).,Pengertian yang lebih umum (dalam arti sempit) dari masyarakat umum adalah bahwa generasi muda adalah kaum muda (remaja dan dewasa awal) ( Muzakkir,2015. Vol 8 No.2)

Seperti yang kita ketahui bahwa generasi muda adalah orang-orang yang akan melanjutkan kehidupan dimasa depan, maka dari itu pentingnya generasi muda muslim untuk bisa memahami dengan baik dari konteks ekonomi Islam terlebih pada bidang ekonomi yang mungkin sekarang orang-orang tidak menganggap atau merespon bahwa riba suatu hal yang biasa saja atau lumrah dilakukan.

\section{METODE PENELITIAN}

Metode penelitian yang digunakan oleh peneliti dalam menyelesaikan penelitian ini ialah menggunakan metode kualitatif, yaitu dalam penelitian ini peneliti mendapatkan data dari hasil menyebar kuesioner, dan dalam prosedur penelitian menghasilkan data deskriptif berupa pemahan generasi muda terhadap bahaya riba. Penelitian kualitatif ini diambil dari jenis studi kasus model penelitian yang membahas tentang individu. Dalam subjek penelitian Kali ini yaitu menyebarkan kuesioner serta membuat beberapa pertanyaan yang terkait dengan pembahan jurnal ini, yaitu pemahaman generasi muda terhadap bahaya riba studi kasus mahasiswa di kota Medan.

\section{HASIL DAN PEMBAHASAN}

Kami telah melakukan survey dengan cara menyebar angket atau kuesioner melalui Google from yang kami sebar kepada generasi muda yang kemudian 
jawaban dari responden akan di tampilkan secara otomatis melalui diagram. Kami mendapatkan 100 responden untuk kuesioner yang telah kami sebar. Rata-rata responden ialah mahasiswa/i yang masih menempuh pendidikan jenjang S1 di beberapa Universitas yang ada di kota medan.

Para responden sangat mengetahui apa itu riba hal ini bisa dilihat dari jawaban responden dimana mereka mengetahui tentang riba. Pemahaman mengenai Riba ini oleh masyarakat khususnya mahasiswa, sehingga apabila mereka sudah mengetahui hal tersebut, maka dapat dipastikan ketika sudah terjun ke masyarakat, pengetahuan mereka tentang riba tidak di ragukan lagiuntuk di implementasikan di dalam kehidupan.

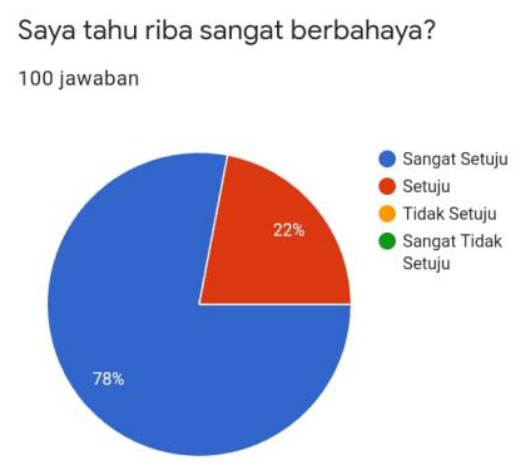

Berdasarkan diagram diatas, $78 \%$ responden mengatakan sangat setuju dengan pernyataan riba sangat berbahaya. Kita sebagai umat muslim mengetahui bahwa riba sangat berbahaya, dan sudah jelas riba itu diharamkan dalam Islam. Bahaya riba yang sangat besar ternyata tidak hanya mengancam kehidupan akhirat seorang muslim. Bahaya riba secara nyata juga dapat berdampak buruk bagi kehidupan baik pada tingkat pribadi maupun masyarakat. Bagi seorang pribadi, riba merupakan cerminan buruknya akhlak karena pelaku riba identik dengan sifat kikir, dada yang sempit, berhati keras, menyembah harta, tamak akan kemewahan dunia dan sifat-sifat hina lainnya. Itu mengapa seharusnya kita menjauhi riba.

Saya lebih mengetahui lembaga keungan syariah?

100 jawaban

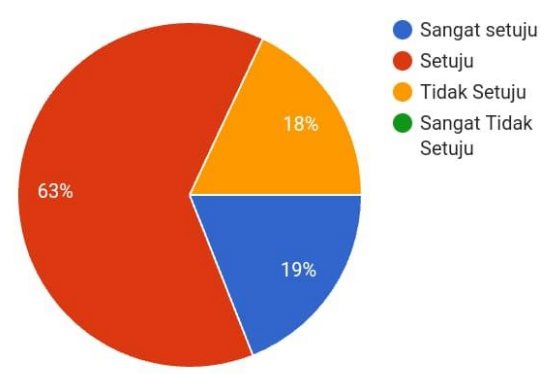

Berdasarkan diagram diatas, 63\% responden menjawab setuju dan $19 \%$ sangat setuju. Lembaga meuangan syariah adalah sebuah lembaga keuangan yang prinsip operasinya berdasarkan pada prinsip-prinsip syariah islamiah. 
Reni Ria Armayani, M.E.I ${ }^{1}$ Wika Lutfiah Sakinah ${ }^{2}$, Desvira Utami Rahmadini ${ }^{3}$, Putri Hermayani ${ }^{4}$, Zizah Chairani ${ }^{5}$

Operasional lembaga keuangan Islam harus menghindar dari riba, gharar dan maisir. Hal- hal tersebut sangat diharamkan dan sudah diterangkan dalam Al- Quran dan Al- Hadist. Dalam lembaga keuangan syariah tidak ada riba, tetapi mereka menerapkan sistem bagi hasil. Sistem bagi hasil ini diterapkan sebagai balas jasa yang diberikan oleh pihak bank kepada nasabah atas penempatan dana dari nasabahnya. Akan tetapi jika kita lihat lagi pada diagram diatas terdapat $18 \%$ menjawab tidak setuju hal ini menunjukkan bahwa masih ada yang tidak mengetahui tentang lembaga keuangan syariah.

Apakah anda setuju jika seseorang di beri makan dari hasil riba akan ikut menanggung dosa? (Dia tidak mengetahuinya)

100 jawaban

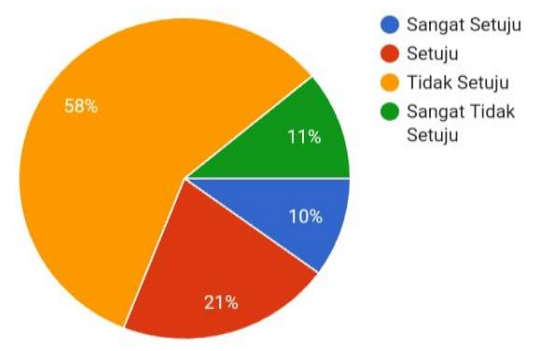

Berdasarkan diagram diatas $58 \%$ responden menjawab tidak setuju dan $11 \%$ menjawab sangat tidak setuju, tetepi masi hada yang menjawan $21 \%$ dan $10 \%$ menjawab sangat setuju dan setuju. Padahal bahwasanya, jika seseorang diberi makan dari hasil riba tetapi orang yang diberi makan tersebut tidak mengetahui bahwa dia diberi makan dari hasil riba, maka orang tersebut tidak ikut menanggung dosanya, karena dosa riba itu hanya jatuh kepada pelaku ribanya, bukan kepada orang yang diberi makan riba. Seperti contohnya seorang anak diberi nafkah oleh ayahnya dari hasil riba, tidak mengapa si anak menerima nafkah dari orang tuanya meski orang tuanya memberikan nafkah kepada anaknya dari hasil riba. Karena keharaman riba ini hanya berlaku untuk pelaku riba.
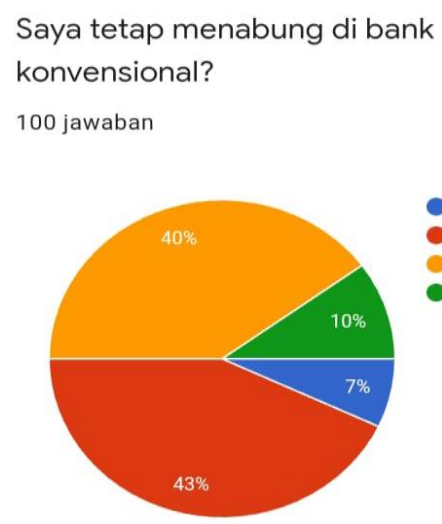

- Sangat Setuju - Setuju

Berdasarkan diagram diatas, $43 \%$ responden menjawab setuju dan $7 \%$ menjawab sangat setuju, hal ini menunjukkan bahwa masih ada muslim 
yang menabung di bank konvensional padahal mereka sudah mengetahui bahwa riba itu haram. Menabung di bank konvensional menurut ajaran Islam tidak diperbolehkan, dikarenakan menabung di bank konvensional terdapat unsur riba di dalamnya. Yakni terdapat tambahan nilai berupa bunga dari uang yang ditabungkan atau dipinjamkan. Dalam hal menyimpan uang tabungan di bank ini, nasabah ibaratnya seperti pemberi pinjaman kepada pihak bank. Sebagai kompensasinya, nasabah akan diberikan imbalan bunga dengan persentase tertentu yang menjadi keuntungan. Keuntungan dari bunga seperti inilah yang diharamkan karena termasuk riba. Maka sebaiknya untuk menghindari riba kita tidak dianjurkan untuk menabung di bank konvensional, tetapi di bank syariah karna tidak terdapat unsur riba di dalamnya

Saya sudah mulai memakai akad dalam sistem jual beli?

100 jawaban

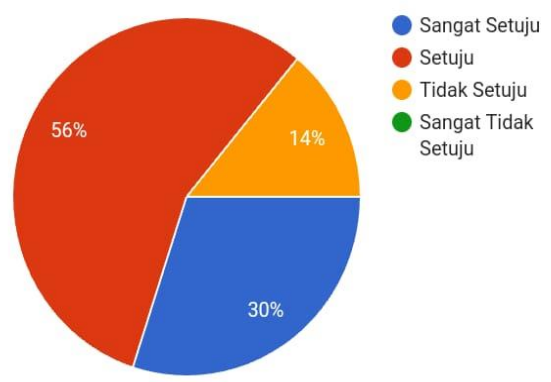

Dalam diagram diatas dapat kita lihat bahwa $56 \%$ responden dan $30 \%$ responden menjawab setuju dan sangat setuju hal ini menunjukan bahwa responden sudah mulai sadar dan memakai akad dalam proses jual beli yang di anjurkan oleh agama kita. Langkah ini sangat baik mengingat bahwa hal seringkali diabaikan oleh masyarakat muslim yang terkadang acuh dan tidak pernah memakai akad dalam transaksi jual beli. Selebihnya sebanyak $14 \%$ menjawab tidak setuju dikarenakan responden belum memakai akad dalam jual beli mungkin saja responden belum terbiasa tetapi alangkah baiknya jika mulai sekarang masyarakat muslim mulai memakai akad dalam transaksi jual beli.
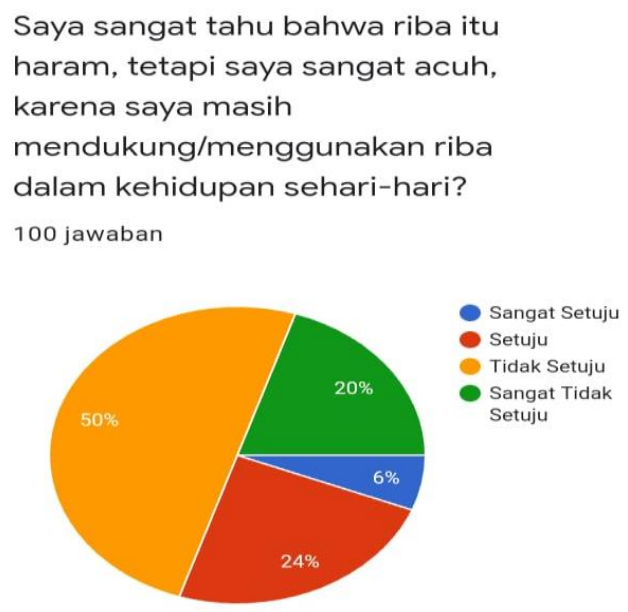

Berdasarkan diagram di atas, bahwa $50 \%$ Responden tidak setuju pada 
saat mengetahui riba itu haram, tetapi masi acuh, dan masi mendukung atau mengunakan riba dalam kehidupan sehari-hari ,karena orang yang menggunakan riba itu tidak dapat berdiri melinkan sebagaimana berdirinya orang yang di rasuki setan dengan terbuyung buyung . karena sudah jelas ketika orang orang masi menggunakan riba itu ,dan sesuatu Riba (tambahan ) itu , yang diberikan agar dia bertambah pada harta manusia , maka Riba itu tidak menambah pahala di sisi Allah SWT.
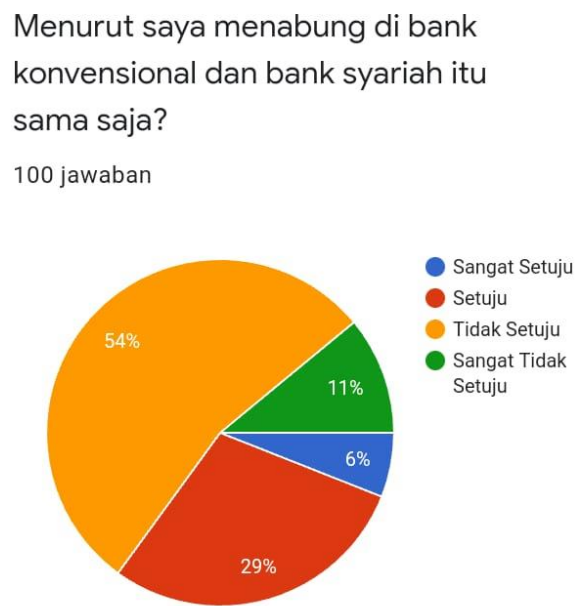

Berdasarkan Diagram di atas ,54 $\%$ Responden tidak setuju dan $11 \%$ sangat tidak setuju menabung di bank konvesional itu sama saja dengan bank syariah karena, kalau di bank konvesional itu memberikan keuntungan keuntungan bagi nasabah yang menempatkan dana nya berupa bunga bank. sementara di sisi lain, bank syariah tidak menerapkan sistem bagi hasil bagi nasabah nya yang seringkali di sebut sebagai biaya sewa modal.
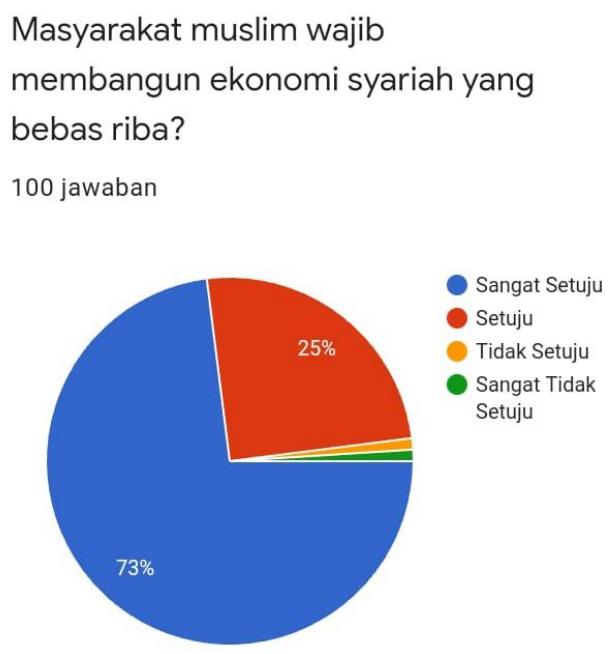

Dari diagram diatas terlihat bahwa responden $73 \%$ sangat setuju jika masyarakat muslim mulai membangun ekonomi Syariah yang bebas dari riba. Hal ini sudah seharusnya dilakukan oleh setiap orang yang beragama islam harus membumikan ekonomi islam, agar kedepannya lebih banyak orang-orang yang paham menjalankan ekonomi Syariah yang bebas riba tidak hanya mengetahui saja tetapi tidak menjalankan. Seperti pada diagram sebelumnya responden sudah mengetahui bahwa riba itu haram, tetepi responden tetep melakan riba tersebut. Maka mulai hari ini kita 
sudah mulai bisa meninggalkan riba dalam kehidupan kita.

\section{PENUTUP}

\section{Kesimpulan}

Berdasarkan hasil penelitian yang dilakukan melalui proses penyebaran angket atau kuesioner pada seratus orang responden, peneliti dapat menyimpulkan hasil dari penelitian terkait analisis pemahaman generasi muda terhadap bahaya riba dengan rincian sebagai berikut:

1. Generasi muda di Kota Medan sudah memiliki pengetahuan mengenai riba dan bahanyanya hal ini dibuktikan dari sekitar $87 \%$ responden memilih opsi sangat setuju saat mengisi kuesioner yang peneliti bagikan.

2. Walaupun pengetahuan generasi muda di Kota Medan tentang riba termasuk tinggi, akan tetapi sekitar $43 \%$ responden tetap memilih untuk menabung di bank konvensional. Hal ini dikarenakan faktor kenyamanan yang ditawarkan dan juga masih banyak yang menganggap bahwa tidak ada perbedaan antara menabung di bank konvensional ataupun menabung di bank syariah.

3. Terdapat lebih dari $73 \%$ generasi muda yang berpendapat bahwa generasi muda muslim harus membangun ekonomi syariah yang bebas riba, akan tetapi mereka tidak yakin apakah mereka bisa terlepas dari riba pada kesehariannya.

Dari ketiga rincian diantas, peneliti mendapatkan gambaran yang sangat jelas bahwa pemahaman generasi muda terhadap riba termasuk dalam kategori belum terlalu baik. Hal ini dapat dilihat dari bagaimana mereka tetap memilih untuk menabung di bank konvensional padahal mereka juga mengetahui bahwa menabung pada bank konvenaional mengandung riba didalamnya.

Generasi muda muslim memang mengetahui bahwa riba itu dilarang dan berbahaya, akan tetapi mereka tidak memahami bahwa kita harus meninggalkan riba bukan hanya karena sekedar dilarang dan berbahaya saja 
melainkan tentang bagaimana cara kita dalam menatati perintah Allah SWT.

\section{Saran}

1. Peneliti sangat berharap kiranya hasil dari penelitian ini dapat menjadi pacuan bagi generasi muda muslim untuk memperdalam pemahamannya mengenai riba. Sehingga ekonomi islam akan bangkit dan bisa menjadi model perekonomian yang sangat berpengaruh bagi seluruh umat manusia.

2. Teruntuk mahasiswa lain yang ingin mengakat tema penelitian tentang pemahaman, dapat mengangkat tema seputar analisis pemahaman generasi muda islam terhadap ekonomi syariah.

3. Peneliti juga berharap kiranya penelitian ini bisa dijadikan sebagai acuan untuk penelitian yang akan mendatang. 


\section{REFERENSI}

Abdullah, M. Faisal. 2005. Manajemen Perbankan, Edisi Kelima. Malang: UMM Press

Brigham, F. 2009. Dasar-Dasar Manajemen Keuangan, Edisi 10. Jakarta: Salemba Empat.

Damayanti, P. 2010. Analisis pengaruh ukuran (SIZE), Capital Adequacy Ratio (CAR), Pertumbuhan deposit, Loan to Deposit Rasio (LDR), terhadap Profitabilitas perbankan Go public Di indonesia tahun 2005 - 2009 (studi empiris perusahaan perbankan yang terdaftar di Bei). Jurnal Ilmu Manajemen dan Akuntansi Terapan. Volume 3 Nomor 2, November 2012. STIE Semarang

Ghozali, I. 2005. Aplikasi Analisis Multivariate dengan Program SPSS. Edisi 3. Semarang: Badan Penerbit Universitas Diponegoro.

Helfert, E. 1997. Analisis Laporan Keuangan Terjemahan Herman Wibowo Jilid 1 Jakarta: Erlangga

Kuncoro, M. dan Suhardjono. 2002. Manajemen Perbankan: Teori dan Aplikasi. Edisi Pertama. Yogyakarta: Salemba Empat

Mamduh, M. Hanafi dan Abdul halim. 2009. Analisi laporan Keuangan. Yogyakarta: UPP STIM YKPN

Muchdarsyah, S. 2000. Manajemen Dana Bank. Edisi ke 2. Jakarta: PT. Bumi Akarsa.

Nahdi, H. Mabchut, Jaryono dan Najimudin. 2012. Pengaruh Current Ratio, Debt to Total Asset Ratio, Total Asset Turnover (TATO), BOPO, dan Dana Pihak Ketiga terhadap Profitabilitas Bank Umum Syariah. Jurnal Manajemen. (http://manajemen.unsoed.ac.id. Diakses 7 April 2014).

Peraturan Bank Indonesia No. 15/12/PBI/2013 tentang Revisi Kewajiban Pemenuhan Modal Minimum Bank Umum di Indonesia.

Sekaran, Uma. 2009. Research Methods for Business 4th Ed, Metodologi Penelitian untuk Bisnis Edisi 4. Buku 2. Jakarta: Salemba Empat

Sofyan, S. 2002. Pengaruh Struktur Pasar terhadap Kinerja Perbankan di Indonesia. Media Riset Bisnis dan Manajemen. Vol.2 No 3. hal.194-219

Sugiyono. 2005. Metode Penelitian Bisnis. Cetakan Ketujuh. Bandung: Alfabeta

Vironika, N.M dan Budiasih 2013. Pengaruh Debt to Equity Ratio, Firm Size, Inventory Turnover dan Assets Turnover pada Profitabilitas. Jurnal Akuntansi Universitas Udayana. ISSN: 2302-8556. No. 5.2 hal.261-273. 